\title{
Distribution of Dry Matter and Chemical Constituents in Plant Parts of Four Florida Native Grasses
}

\author{
R.S. KALMBACHER
}

\begin{abstract}
Because of the selective nature of grazing livestock, the use of whole plant samples to estimate the nutritional potential of forages may be misleading. During this 2-year study, the distribution of dry matter (DM), crude protein (CP) in vitro organic matter digestibility (IVOMD), and concentrations of $P, \mathrm{~K}, \mathrm{Ca}, \mathrm{Mg}, \mathrm{Mn}$, $\mathrm{Fe}, \mathrm{Cu}$, and $\mathrm{Zn}$ were determined in the individual leaf blades, leaf sheaths, nodes plus internodes, and infloresences of creeping bluestem (Schizachyrium stoloniferum), lopsided indiangrass (Sorghastrum secundum), maidencane (Panicum hemitomon), and wiregrass (Aristida stricta) when they were in the anthesis stage of, maturity. Most of the DM was in the nodes plus internodes (avg. 45\%), while the leaf blades (avg. 18\%) generally made up the smallest amount of the total plant DM. In a progression from the bottom to top of the plant the CP, IVOMD, and most of the mineral concentration of the different leaf blades, sheaths, and nodes plus internodes increased. Crude protein, IVOMD, and most of the minerals of the grasses were higher in leaf blades, followed by sheaths, and nodes plus internodes. When compared with other grasses, maidencane had a higher proportion of $\mathrm{CP}$ and minerals in the leaves and nodes plus internodes and a higher percentage of plant weight in these parts. Wiregrass was found to be similar to creeping bluestem and indiangrass in CP and most minerals, but IVOMD of wiregrass parts were lower. Dietary requirements for dry, pregnant cows for $\mathrm{P}, \mathrm{N}, \mathrm{Mg}$, and $\mathrm{Cu}$ might not be met by any part of the 4 grasses, while apparently adequate levels of $\mathrm{Fe}, \mathrm{Mn}$, and $\mathrm{Zn}$ could be provided by each part. Leaf blades and infloresences had sufficient $C a$ concentrations for dry pregnant cows.
\end{abstract}

When evaluating pasture quality, the nutritional potential of forage may be underestimated by analyzing whole plant samples. Cattle seldom consume whole plants, but rather selectively graze individual parts. The parts of a plant [infloresence, leaf blade, leaf sheath, and culm (nodes plus internodes)] differ in their chemical and physical properties depending on their role in the plant.

Florida's sub-tropical native forage grasses are low in protein, digestibility and mineral concentration (Kalmbacher 1981a, $198 \mathrm{lb}$ ). This is associated with low soil fertility and high temperature during the growing season and the advanced plant maturity in winter when most Florida range is grazed. Because evaluation of whole plant samples can be misleading, this study was initiated to examine the distribution of dry matter (DM), the variation in crude protein (CP), in vitro organic matter digestibility (IVOMD), and the concentration of certain minerals in parts of 4 important grasses. The major increaser on flatwoods range, wiregrass (Aristida stricta); 2 major decreasers on flatwoods, creeping bluestem (Schizachyrium stoloniferum) and lopsided indiangrass (Sorghastrum secundum); and the major decreaser on slough sites, maiden-

Author is associate agronomist, Ona Agricultural Research Center, Box 62, Ona, Florida 33865.

This report is Florida Agricultural Experiment Station Journal Series No. 3673. Manuscript received March 20, 1982. cane (Panicum hemitomon), were studied.

\section{Materials and Methods}

In January 1976 creeping bluestem, indiangrass, maidencane, and wiregrass were collected from nearby range and were transplanted into 330 -foot rows at the University of Florida's Ona Agricultural Research Center in the south-central part of the state. The soil (Eau Gallie fine sand, a sandy siliceous hyperthermic Alfic Haplaquod) was unlimed and unfertilized with a $\mathrm{pH}$ of 4.1 and the measured double acid-extractable (exchangeable) nutrients were as follows: phosphorus (P), $8 \mathrm{~kg} / \mathrm{ha}$; potassium $(\mathrm{K}), 45 \mathrm{~kg} / \mathrm{ha}$; calcium $(\mathrm{Ca}), 500 \mathrm{~kg} / \mathrm{ha}$; and magnesium $(\mathrm{Mg}), 125 \mathrm{~kg} / \mathrm{ha}$; and the organic matter content was $2.5 \%$.

In February 1977 and 1978 plants were burned and allowed to regrow until anthesis (flowering), which occurred between midAugust and late September, depending on species. At anthesis 100 tillers from each of creeping bluestem and indiangrass and 200 tillers from each of maidencane and wiregrass were cut at the soil surface in each of 3 rows and composited by species. Plants were brought to the laboratory and were rinsed to remove sand from the stem base. Tillers were divided into parts: individual leaf blades, green leaf sheaths, nodes plus internodes (excluding the basal internode), and infloresence. The parts were numbered from the bottom to top of the shoot, dried, weighed to determine dry matter distribution, then ground and analyzed for CP (Nitrogen $\times 6.25)$, in vitro organic matter digestibility (IVOMD), $\mathbf{P}, \mathbf{K}, \mathrm{Ca}, \mathrm{Mg}$, Iron (Fe), Manganese (Mn), Copper $(\mathrm{Cu})$, and $\mathrm{Zinc}(\mathrm{Zn})$. The methods described by Gallaher et al. (1977) and Isaac and Johnson (1976) were used for $N$ analysis, and that of Moore et al. (1972) for IVOMD. All mineral determinations involved dry ashing at $450^{\circ} \mathrm{C}$ for 2 hours. Ash was put in solution with $2 \mathrm{ml}$ of deionized water followed by $20 \mathrm{ml}$ of concentrated $\mathrm{HCl}$ and evaporated to dehydrate silica. After cooling, $20 \mathrm{ml}$ of deionized water followed by 2.5 $\mathrm{ml}$ of $40 \% \mathrm{HCl}$ were added and brought to a boil. The residue was filtered and brought up to a $50 \mathrm{ml}$ volume. Phosphorus concentration was determined by a Technicon Auto Analyzer, and all other minerals were determined by atomic absorption methods. These data represent the means of 2 years with 1 analytical and sampling replication per year.

\section{Results and Discussion}

\section{Distribution of Dry Matter (DM)}

The greatest proportion of DM was found in the node plus internode tissue (Table 1), which ranged from $38 \%$ in indiangrass to $54 \%$ in creeping bluestem. The other grasses had 42 to $46 \%$ of their DM in the nodes plus internodes. Leaf blades contained the lowest amount of DM, averaging $18 \%$. Dry matter levels in the leaf blades of creeping bluestem, indiangrass, and wiregrass were similar with 12 to $14 \%$, but maidencane had $35 \%$ of its DM in the leaf blades. The proportion of plant DM in the leaf sheaths averaged $22 \%$ and was similar in creeping bluestem, maidencane and wiregrass, but nearly twice as high in indiangrass (39\%). Except for 
Table 1. Distribution of dry matter and concentration of phosphorus, potassium, calcium, and magnesium in the various plant parts of 4 native grasses at the anthesis stage of maturity. Ona, Fla. Averages of 1977 and 1978.

\begin{tabular}{|c|c|c|c|c|c|}
\hline \multirow[b]{2}{*}{ Grass } & \multicolumn{4}{|c|}{ Plant part } & \multirow[b]{2}{*}{$\begin{array}{l}\text { Weighted } \\
\text { plant avg. }\end{array}$} \\
\hline & $\begin{array}{l}\text { Leaf } \\
\text { blade }\end{array}$ & $\begin{array}{l}\text { Leaf } \\
\text { sheath }\end{array}$ & $\begin{array}{l}\text { Node and } \\
\text { internode }\end{array}$ & Inflor. & \\
\hline \multicolumn{6}{|c|}{ Distribution $(\%)$ of dry matter } \\
\hline C. bluestem & 12 & 13 & 54 & 21 & \\
\hline Indiangrass & 12 & 39 & 38 & 11 & \\
\hline Maidencane & 35 & 19 & 46 & 0 & \\
\hline Wiregrass & 14 & 16 & 42 & 28 & \\
\hline Avg. & 18 & 22 & 45 & 20 & \\
\hline \multicolumn{6}{|c|}{ Phosphorus\% } \\
\hline C. bluestem & 0.09 & 0.06 & 0.03 & 0.08 & 0.05 \\
\hline Indiangrass & 0.04 & 0.04 & 0.06 & 0.09 & 0.05 \\
\hline Maidencane & 0.05 & 0.04 & 0.08 & - & 0.06 \\
\hline Wiregrass & 0.07 & 0.06 & 0.08 & 0.08 & 0.08 \\
\hline Avg. & 0.06 & 0.05 & 0.06 & 0.08 & 0.06 \\
\hline \multicolumn{6}{|c|}{ Potassium\% } \\
\hline C. bluestem & 0.39 & 0.43 & 0.49 & 0.39 & 0.45 \\
\hline Indiangrass & 0.18 & 0.32 & 0.75 & 0.43 & 0.47 \\
\hline Maidencane & 0.39 & 0.43 & 0.50 & - & 0.45 \\
\hline Wiregrass & 0.22 & 0.31 & 0.48 & 0.59 & 0.45 \\
\hline Avg. & 0.29 & 0.37 & 0.55 & 0.47 & 0.46 \\
\hline \multicolumn{6}{|c|}{ Calcium $\%$} \\
\hline C. bluestem & 0.16 & 0.06 & 0.04 & 0.24 & 0.10 \\
\hline Indiangrass & 0.28 & 0.10 & 0.06 & 0.08 & 0.10 \\
\hline Maidencane & 0.36 & 0.12 & 0.04 & - & 0.14 \\
\hline Wiregrass & 0.32 & 0.12 & 0.06 & 0.30 & 0.22 \\
\hline Avg. & 0.28 & 0.10 & 0.05 & 0.20 & 0.14 \\
\hline \multicolumn{6}{|c|}{ Magnesium $\%$} \\
\hline C. bluestem & 0.06 & 0.04 & 0.04 & 0.05 & 0.03 \\
\hline Indiangrass & 0.06 & 0.03 & 0.04 & 0.04 & 0.03 \\
\hline Maidencame & 0.10 & 0.10 & 0.06 & - & 0.08 \\
\hline Wiregrass & 0.10 & 0.09 & 0.08 & 0.08 & 0.08 \\
\hline Avg. & 0.08 & 0.06 & 0.06 & 0.06 & 0.06 \\
\hline
\end{tabular}

maidencane, which seldom flowers, infloresence DM was lowest in indiangrass, intermediate in creeping bluestem and highest in wiregrass.

\section{Crude protein (CP)}

Leaf blade CP was greater than that found in other plant parts (Figure 1). The CP increased from plant bottom to top because of the gradient of older to younger tissue. Maidencane leaf blade CP (weighted avg. $7.8 \%$ ) was greater than creeping bluestem $(6 \%)$, wiregrass $(4 \%)$, and indiangrass $(4 \%)$. Weighted averages of leafsheath CP were similar in all grasses (2 to $3 \%$ ). The nodes plus internodes of maidencane tended to be higher in CP than the other grasses, especially in the upper third of the plant where CP ranged from 3 to $6 \%$ (Fig. Ic). Infloresence CP was $5 \%$ in creeping bluestem, $5 \%$ in indiangrass, and $4 \%$ in wiregrass. Whole plant $\mathrm{CP}$ for the grasses was: creeping bluestem, $3 \%$; indiangrass, $3 \%$; maidencane, $5 \%$; and wiregrass, $3 \%$.

\section{Digestibility (IVOMD)}

Leaf blade IVOMD, (Fig. 2a), like leaf blade CP, tended to be higher than in other plant parts (Figs. 2b, 2c), and IVOMD increased from the plant bottom to plant top. An exception to this was leaf blade IVOMD of creeping bluestem, which was nearly the same from leaf 1 to leaf 6 , but these values tended to be more than 10 percentage units greater than the weighted averages of other grass leaves (creeping bluestem, 39\%; maidencane, 28\%; indiangrass, $25 \%$, wiregrass $25 \%$ ). The upper leaves of maidencane had IVOMD values between 30 and $40 \%$. The IVOMD values for the leaf sheaths of creeping bluestem (weighted avg. 27\%), indiangrass, (avg. 33\%), and maidencane (avg. 33\%) were similar, but that for wiregrass (13\%) was low (Figure 2b). Weighted average IVOMD of the nodes and internodes (Figure $2 \mathrm{c}$ ) of indiangrass $(38 \%)$ was greater than maidencane (30\%). Creeping bluestem IVOMD (23\%) was similar to wiregrass (19\%). Infloresence IVOMD was $35 \%$ in creeping bluestem, $29 \%$ in indiangrass and $27 \%$ in wiregrass. Whole plant IVOMD was: bluestem, $28 \%$, indiangrass, $33 \%$; maidencane, $30 \%$; and wiregrass, $20 \%$.

Hacker and Minson (1981) published a review of the digestibilities of temperate and tropical plant parts. Leaf blade digestibility of grasses ranged from 46 to $81 \%$ and increased from plant bottom to top. The IVOMD of the stem fraction differed greatly among species, ranging from 5 to $85 \%$. They also reported that the infloresence digestibility of several grasses averaged $61 \%$ and ranged 18 percentage units within a species. The digestibility data from our Florida range grasses are generally lower than those reported by Hacker and Minson (1981), but relative differences among plant parts and gradients within the plant are similar.

\section{Plant P, K, Ca, Mg Content.}

Most of the weighted averages for mineral concentration from this study are lower than those published for creeping bluestem in the vegetative stage (Kalmbacher 1981a). In this study all grasses were burned, and burning promotes reproductive growth (White and Terry 1980). There were few practical differences in P concentration among species (Table 1), and the weighted plant averages ranged from 0.05 to $0.08 \% P$. Infloresences tended to be higher in $P$ than other parts, but it is usual for the reproductive parts to have 


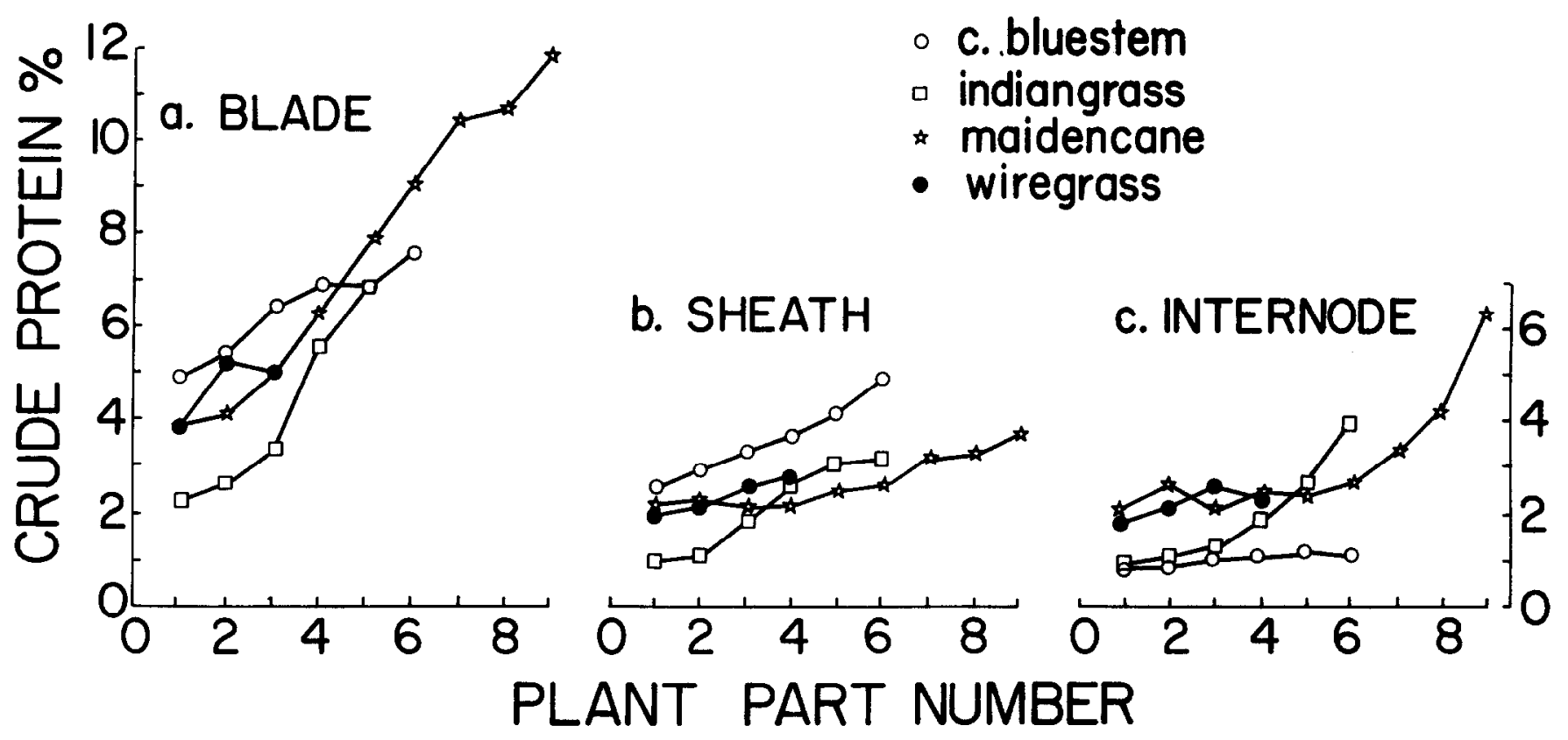

Fig. 1. Crude protein concentration in the leaf blades (a), leaf sheaths (b), and nodes and internodes (c) in 4 native grasses at anthesis with 1 being the bottom of the plant and 9 the top. Ona, Fla. Averages 1977 and 1978.

higher $P$ (Smith 1976). A gradient in $P$ concentration in all grasses was found with higher values at the top of the plant. For example $P$ concentration in maidencane leaf blades ranged from 0.02 to $0.10 \%$, sheaths 0.02 to $0.07 \%$ and internodes 0.06 to $0.12 \%$ from bottom to top, respectively. Weighted averages of these and similar values were used to obtain the weighted plant values reported in Table 1.

Plant $\mathrm{K}$ concentration was very similar among the grasses averaging $0.46 \%$ (Table 1 ). The nodes and internodes were generally greatest in $\mathrm{K}$ concentration, blades and sheaths were lowest, while the inflorescence was intermediate. Strong trends toward increasing $K$ concentration in all plant parts were found from the bottom of the plant to the top. For example, $\mathrm{K}$ concentration in maidencane leaves ranged from 0.04 to $0.6 \%$; sheaths, 0.06 to $0.73 \%$ and nodes plus internodes, 0.39 to $0.84 \% \mathrm{~K}$ in the bottom and top, respectively.
Calcium concentration in the grasses ranged from 0.10 to $0.22 \%$ and averaged $0.14 \%$ (Table 1 ). Leaf blades $(0.28 \%)$ were higher in $\mathrm{Ca}$ than other plant parts and nodes plus internodes were lowest $(0.05 \%)$. Calcium concentration increased from the bottom to the plant top, and leaf blades showed more of an increase than other parts.

Magnesium concentration averaged $0.06 \%$ (Table 1). Creeping bluestem and indiangrass were lower in $\mathrm{Mg}$ than maidencane and wiregrass. Leaf blades were $0.08 \% \mathrm{Mg}$ and each of the other plant parts averaged $0.06 \% \mathrm{Mg}$. There was a small $(0.01$ to $0.02 \%)$ increase in $\mathrm{Mg}$ from plant bottom to top of three grasses, but in maidencane an increase of 0.05 to $0.06 \% \mathrm{Mg}$ was found in blade and stem tissue.

There was more of a top to bottom gradient in the concentration of $\mathbf{P}, \mathrm{K}$, and $\mathrm{Ca}$ within maidencane parts than there was variation in the averages for that maidencane part compared with the

\section{-c. bluestem aindiangrass Æmaidencane - wiregrass}

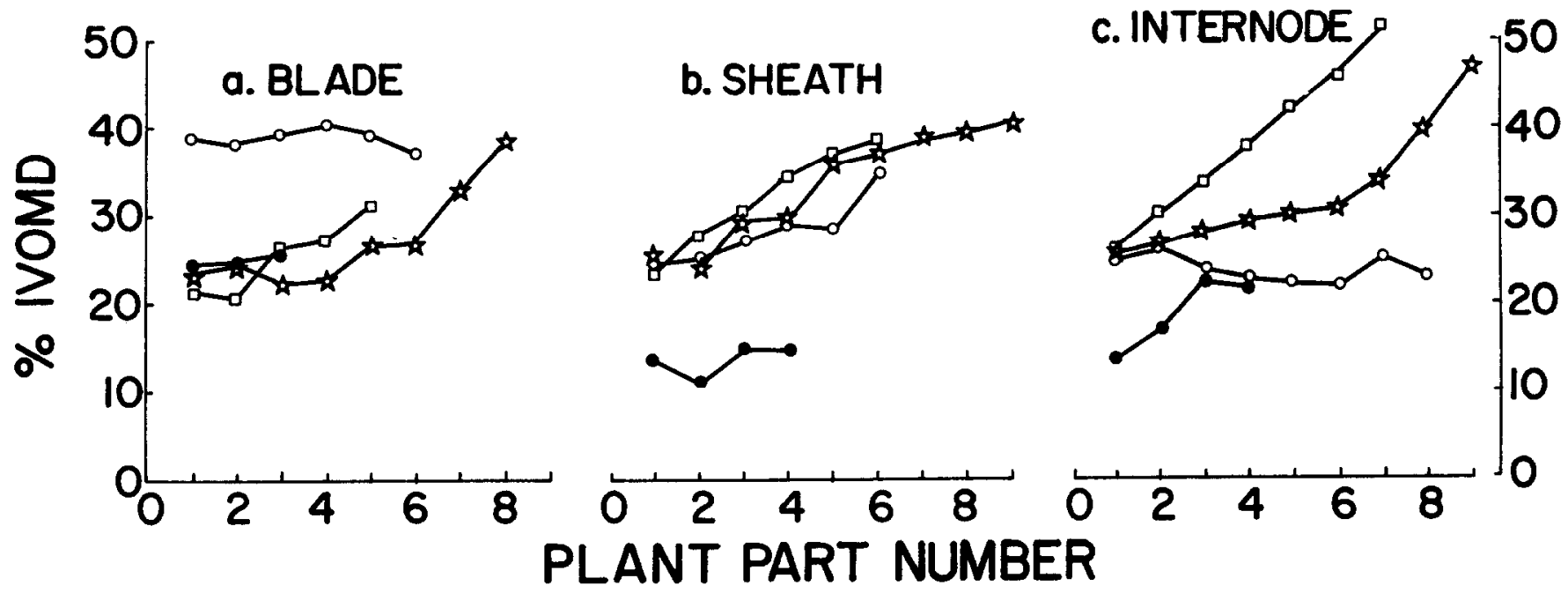

Fig. 2. In vitro organic matter digestibility (IVOMD) of the leaf blades (a), leaf sheaths (b), and nodes and internodes (c) in 4 native grasses at anthesis with 1 being the bottom of the plant and 9 the top. Ona. Fla. Averages of 1977 and 1978. 
average $P, K$, and $\mathrm{Ca}$ concentration in the same part of another grasses. The other grasses did not have this great range in concentration from top to bottom. Creeping bluestem (rhizomatous), wiregrass, and indiangrass (bunch grasses) have fewer leaves, and nodes plus internodes than maidencane (Figs 1 and 2), and they have different morphology than maidencane. Maidencane is upright with many leaves inserted along the culm, and the 4 lower leaves are shaded and senescent.

\section{Plant Fe, Mn, $\mathrm{Cu}$, and $\mathrm{Zn}$}

The whole plant concentration of these trace elements averaged 34 ppm Fe; 35 ppm Mn; 2 ppm Cu and 25 ppm Zn (data not in table). Blades were usually highest in all elements $(50 \mathrm{ppm}$ Fe; 55 ppm Mn; 2 ppm $\mathrm{Cu} ; 15$ ppm $\mathrm{Zn}$ ), followed by infloresences (30 ppm Fe; 44 ppm Mn; 2 ppm Cu; 24 ppm Zn). Mineral concentration were lowest in internodes (17 ppm Fe; $17 \mathrm{ppm} \mathrm{Mn;} \mathrm{trace} \mathrm{Cu}$; $41 \mathrm{ppm} \mathrm{Zn}$ ) and intermediate in sheaths (28 ppm Fe; 28 ppm Mn; trace $\mathrm{Cu} ; 16 \mathrm{ppm} \mathrm{Zn}$ ).

\section{Conclusions}

Concentration of CP, minerals and IVOMD differed within the plant. Creeping bluestem, lop-sided indiangrass, and wiregrass had higher concentrations of $\mathrm{CP}$ and minerals and higher IVOMD in the leaf blades followed by decreasing concentrations in the infloresence, leaf sheaths, and nodes and internodes, respectively. Maidencane was found to have higher levels of the measured chemical constituents in the leaf blades, followed by lesser concentration in the nodes plus internodes and leaf sheaths, respectively.

Not only do these grasses differ in chemical constituents, but also in their distribution of DM. Maidencane has a high proportion of CP and minerals in the leaves and nodes plus internodes, and this, coupled with a high percentage of the plant weight in these parts, makes maidencane a more nutritious grazing plant. Wiregrass was found to be similar to creeping bluestem and indiangrass in CP and most mineral elements as well as distribution of DM, but the digestibility of all wiregrass parts was lower.

The dietary requirements (NRC, 1976) of dry pregnant cows for $\mathrm{P}, \mathrm{K}, \mathrm{Mg}$, and $\mathrm{Cu}$ might not be met by any plant part of any of the 4 grasses studied. Dry, pregnant cows could receive sufficient $\mathrm{Ca}$ from the leaves and infloresences of these grasses. Adequate levels of $\mathrm{Fe}, \mathrm{Mn}$, and $\mathrm{Zn}$ are apparently provided by each plant part of the 4 grasses.

When sampling native pastures to assess the need for protein, energy or mineral supplementation, range managers should not sample whole plants, but rather the portions of the forages that cattle are eating at the time of sampling. This should provide a more accurate representation of the diet.

\section{Literature Cited}

Gallaher, R.N., C.O. Weldon, and F.C. Boswell. 1977. A semi-aut omated procedure for total nitrogen in plant and soil samples. Soil Sci. Soc. Amer. Proc. 40:887-889.

Hacker, J.B., and D.J. Minson. 1981. The digestibility of plant parts. Herbage Abstracts. 51:459-482.

Isaac, R.S., and W.C. Johnson. 1976. Determination of total nitrogen in plant tissue using a block digester. J. Ass. of Anal. Chem. 69:98-101.

Kalmbacher, R.S., and F.G. Martin. 1981a. Mineral content in creeping bluestem as affected by time of cutting. J. Range Manage. 34:406-408.

Kalmbacher, R.S., F.G. Martin, and J.M.S. Andrade. 1981b. Yield and quality of creeping bluestem as affected by time of cutting. J. Range Manage. 34:471-474.

Moore, J.E., G.O. Mott, D.G. Dunham, R.W. Omer. 1972. Large capacity in vitro OM digestion procedure. J. Anim. Sci. 35:232. Abstract No. 261.

National Research Council, Subcommittee on Beef Cattle Nutrition. 1976. Nutrient requirements of beef cattle. Printing and Publishing Office, Nat. Acad. Sci., Washington, D.C.

Smith, D. 1973. Distribution of dry matter and chemical constituents among the plant parts of six temperate-origin forage grasses at early anthesis. Res. Rep. R 2552. Wisconsin Agr. Exp. Station. Madison.

White, L.D. and W.S. Terry. 1979. Creeping bluestem response to prescribed burning and grazing in south Florida. J. Range Manage. 32:369-

\section{GRASS SYSTEMATICS}

\section{By FRANK W. GOULD and ROBERT B. SHAW}

Revised to reflect changes in agrostology since the 1969 edition, the principal emphasis of this book is on the structure and growth of the grass plant and on the characteristics of the grass genera of the U.S. Discussion of tribes and subfamilies relates particularly to grasses of subtropical and temperate North America, but reference is also made to worldwide representatives of these groups. The listings of genera and higher taxa are in phylogenetic sequence, and the key to U.S. genera is based on the most readily observable characters of the inflorescence. Earlier books by Dr. Gould are The Grasses of Texas and Common Texas Grasses.

416 pp. 185 illus. Maps. Tables. Glossary. Refs. \$25.00 cloth; $\$ 15.00$ paper

\section{BRUSH MANAGEMENT} Principles and Practices for Texas and the Southwest By Charles J. Scifres

This book is a comprehensive guide to rangeland brush management, including discussion of specific brush problems and practical methods of control, the impact on the environment, and specialized control systems. 376 pp. 92 illus. $\$ 17.50$

TEXAS A\&M UNIVERSITY PRESS, Drawer C, College Station, Texas 77843-4354 